\title{
Effects of streaming in P1 (former group A) primary schools in Mutare urban, Zimbabwe
}

\author{
Elliott Nkoma \\ Great Zimbabwe University Faculty of Social Sciences Department of Psychology P.O. Box 1235, Masvingo, \\ Zimbabwe
}

\begin{abstract}
The purpose of the study is to determine the effects of streaming on grade 5 pupils' academic achievement in P1 (Former group A) primary schools in Mutare Urban, Manicaland. Two primary schools were selected (one streaming school was randomly selected while the non-streaming school was purposely selected). A quasi-experimental design was opted. A sample size of 345 (males=169; females=176) was purposely selected of which 152 pupils (males $=72$; females $=78$ ) were from a non-streaming school, while 193 pupils (males $=95$; females $=98)$ were from a streaming school. An adapted Wide Range Achievement test L1 revised for mathematics subtest was used to test for achievement levels. The results indicate a high significant difference $(t(345)=-104.24, \alpha=0.01)$ between non-streaming and a steaming schools. Girls were more represented in the high stream (70\%) while boys were more in the middle streams (57\%) and low stream (65\%). The achievement levels decreases as pupils find themselves in lower streams and the grade equivalent differences (achievement lag) between high and low stream classes translates to 4 years of education while that of a non-streaming school is one year. Greater variability in test scores were found in the streaming school ( $(s=4.37)$ than nonstreaming school $(s=2.91)$.

Key words: Achievement, Lag, Mathematics, Stream, Equivalent
\end{abstract}

\section{Background}

When children enter school, they bring individual differences in areas of previous academic achievement, cognitive attainments, temperament and home background. Schools hence respond to these differences by providing instructional approaches that suit individual students' needs, capacities, learning styles and prior academic achievements. Such a premise makes schools group students according to ability so that teachers tailor their instruction to a homogeneous group of students studying at the same pace (Irvin and Larson, 2001; Allington, 1994). Bright students are assumed to require enriched material and need a faster pace of learning while slow students benefit from repetition, remediation and frequent reviews.

Slavin (1987) cited some grouping forms at elementary schools as within-class grouping, abilitygrouped class assignment or between-class grouping, ability grouping for selected subjects, the Joplin plan, special classes for the gifted classes or low achievers. Within-class ability grouping is where a teacher groups pupils within his or her class according to ability. Thus allowing teachers to divide their time among specific subgroups and provide instruction which is sensitive to the needs and abilities of one group, while other groups engage in more non-teacher-directed instructional activities (Slavin, 1987). Ability-grouped class assignment or between classes ability grouping (sometimes referred to as tracking or streaming) pupils are assigned to a self contained class on the basis of ability or achievement. Ability grouping for selected subjects requires pupil assignment to homogeneous class for a particular subject or two according to achievement while they spend most of the day in a heterogeneous homeroom class. The Joplin plan is where pupils regardless of their grade levels meet for reading in a homogeneous class based on their achievement levels. Special classes for high achievers seek to bring together gifted, talented or superior pupils for part or all of the school day while their normal peers remain in relatively heterogeneous classes. Similarly, special classes for low achievers bring together pupils with learning problems for part or all of their school day.

However, Slavin and Braddock (1993) view ability grouping as not effective. Their criticisms to ability grouping can be summarized as:

1. The outcome of ability grouping is that students in low ability groups are exposed to substantially less material and to lower quality of instruction than students in the middle or high ability groups.

2. The pro-grouping argument is mainly concerned with effectiveness while the anti-group is concerned with equity and democratic values. They argue that proponents of ability grouping fail to meet this burden of proof clearly showing the effectiveness of grouping enabling to sacrifice the needs of low achievers in favor of high achievers. 
3. Students in low-ability groups are likely to be exposed to more low-level skills than are students in the middle and high groups.

4. The feelings of inferiority and worthlessness may be the outcome of students in low ability groups

5. Students in the low track are still more likely to be delinquent than are other students and are less likely to complete their education.

The above supports the differential effects hypothesis of ability grouping.

The focus of this research is to determine the effects of between classes grouping at primary school level which is sometimes called streaming in Zimbabwe. Streaming can be defined here as the method of assigning pupils to classes on some overall assessment of ability. This is a school wide arrangement by which students are assigned to classes. According to Kulik (1992), teachers and administrators divide students into separate classes on the basis of their perceived abilities or prior knowledge. There is no policy on streaming at primary school level in Zimbabwe but at secondary level. The researcher has been an Educational Psychologist in The Ministry of Education and had noted that several primary schools practice streaming but follow the same syllabus and subjects with non-streaming primary schools. Pupils remain with one teacher for the whole day (similar to schools which do not stream) and this allows for strong relationships to be built between pupils and teacher which relationship is positively linked to student achievement (Moos, 1979). The purpose of the study is to determine if there are any achievement differences between streamed and non-streamed P1 (former group A) primary schools in Mutare urban. P1 primary schools (formerly group A schools) are located in former European affluent suburbs and were formerly attended by Whites, Indians and Colored students only and the schools were superior in terms of resources and trained teachers. Access to schools by pupils is based on residence. Hence, only those African pupils with high socioeconomic status parents and lived in former white suburbs could enroll in P1 (former group A) schools (Atkinson, 1982; Zindi, 1996). The main educational emphasis in Zimbabwe is on increasing educational standards after the regressed learning and subdued teaching caused by the country's economic melt-down (see Nkoma et al., 2012). Primary schools hence, assume that the best way to maximize academic success was by selective grouping. More specifically the study will look at within school variances and achievement differences between grade 5 schools that stream and not using standardized achievement tests.

According to Ireson and Hallam, (2001) ability grouping enables teaching to be effectively geared towards students of diverse abilities, allowing the most capable to reach the highest standards in each group. However, Oakes (1985) argues that teachers develop lower expectations for students in lower ability groups which deny them appropriate opportunities to learn and advance academically. Jung (2000) found that high ability group had more learning opportunity time than the low ability group and more time was spent on discipline issues than the high ability group. The low group students reported that they do not have student who could have acted as a role model for them. Similarly, studies on streaming in Zimbabwe have focused on secondary schools (Chisaka, 1996; Matavire, Mukavhi and Sana, 2012), and the findings indicate that low ability groups receive differential treatments and instructions from teachers and are stereotyped and labeled by other students and teachers.

Research studies indicate that high-achieving students achieve at same levels in tracked and untracked groups but the middle and low achieving students score at significantly higher levels when they are not working in tracks ( Nunes, Bryant, Sylva and Barros, 2009; Boaler, 2002, 2008a; Borris, Heubert and Levin, 2006). A study involving 660 primary schools in the United Kingdom, found that streaming had negative effects including inequity, inaccurately formed groups, lowering students' self efficacy, and lowered standards for some groups (Jackson, 1964 cited by Macqueen,2010). According to Boaler, (2011) heterogeneous classrooms based on cooperation among students change student perceptions of who they are and who they can be and they teach students about the different qualities and contributions of students who are different from themselves (Boaler, $2008 \mathrm{a}, \mathrm{b})$ and they challenge racial segregation in schools.

Studies on ability grouping have focused on teachers attitudes and beliefs about ability grouping (Hallam and Ireson, 2003), students preferences for different types of ability grouping (Boaler, et al., 2000; Hallam and Ireson, 2006), and the effects of ability on subject attainment (Ireson, et al., 2005). There is little or no research in Zimbabwe on primary school streaming and most researchers have focused on secondary schools using qualitative research. It is against this background that the study will determine variations in pupils' achievement in streamed and non-streamed Mutare urban P1, primary schools.

\section{Purpose of study}

The purpose of the study is to determine if there is equity in achievement levels within schools that stream and not (variation in pupils' achievement scores within the school), differences in achievement levels between non-streaming and steaming schools and also gender disparities in streamed classes. 


\section{Research questions}

1. Are there any disparities by gender in schools that stream?

2. Are there any variations of pupils' mathematics achievement between schools that stream and not?

3. Are there any achievement differences in different grade 5 classes in non-streaming and streaming schools?

\section{Hypothesis}

Ho: There are no significant differences in pupils' mathematics achievement between non-streaming and streaming grade 5 pupils.

\section{Research design}

\section{Methodology}

To determine the variability of grade 5 pupils' achievement levels in Mutare urban, P1 primary schools the researcher opted for a quasi-experimental design -a non-equivalent groups design. This is necessary because one school streams while the other does not and they are all located in low density areas. Participants were not randomly assigned to treatment groups. Nevertheless, because it is applicable in so many circumstances, the non-equivalent groups design is the most commonly implemented research designs in the social sciences (Campbell and Stanley, 1963; Shadish, Cook and Campbell, 2002).

\section{Population}

There are three P1, Mutare urban primary schools and one of these does not practice streaming. All grade 5 pupils were targeted.

\section{Sample}

One of the two P1 schools which stream was randomly selected while the one which does not stream was purposively selected. Schools were matched according to location. All grade 5 pupils in the two schools participated in the study. A total sample size of 345 pupils $(\mathrm{M}=169 ; \mathrm{F}=176)$ participated.

Table 1. Class sizes in schools $\mathrm{X}$ and $\mathrm{Y}$

\begin{tabular}{|l|l|l|l|}
\hline \multicolumn{2}{|c|}{ School X } & \multicolumn{2}{c|}{ School Y } \\
\hline Class & Class size (n) & Class & Class size (n) \\
\hline A & 58 & A & 50 \\
\hline B & 46 & B & 41 \\
\hline C & 48 & C & 42 \\
\hline & & D & 40 \\
\hline & & E & 20 \\
\hline Total & 152 & Total & 193 \\
\hline
\end{tabular}

School $\mathrm{X}$ (which does not stream) has three grade 5 classes having a total of 152 pupils $(\mathrm{M}=74 ; \mathrm{F}=78)$. School Y has 5 streams of which class A has the best pupils (high stream), followed by class B, and class E being the lowest stream. A total of 193 pupils $(\mathrm{M}=95 ; \mathrm{F}=98)$ from school Y participated in the study.

\section{Instruments}

A structured questionnaire for teachers and Head-teachers was administered to three grade 5 teachers in each school and two Head-teachers $(n=8)$. The questionnaire focused on teacher attitudes and beliefs about steaming (see annex 1). A Wide Range Achievement test Level 1 (mathematics subtest) was used to determine pupils' achievement levels (annex 2). Pupils were assessed during school hours in their respective classrooms and one invigilator was assigned to each class. The tests took 30 minutes to administer. The teachers were allowed to respond to the questionnaires at their own time.

\section{Analysis}

Both qualitative and quantitative data analyses were used. Pupils' mean scores for each grade were converted to grade equivalence. The Zimbabwe education system is divided into three terms and each school term has 3 months. Assessments were done towards the end of first term in March. These pupils' ought to be achieving at lower fifth grade level, which is $\mathbf{5 B}$ with a score of $\mathbf{3 0}$ on mathematics subtest (see annex 2). This is a grade equivalent score. The obtained mean scores for each grade and or class were transformed to equivalent grade levels. 


\section{Results}

The headmaster is responsible for allocating teachers in their respective classes and the more experienced teachers are given high streams and less experienced low streams. There is no rotation of teachers in high, low and middle streams and pupils are tested once at the end of the year and changed streams depending on their school based test scores. Streaming begins at grade 2 level. All teachers in school Y agreed that academic standards would suffer if they stopped streaming but a teacher in the low stream preferred rotation of different streams. All teachers agreed that the high teacher-pupil ratio impact negatively on teaching and teacher-pupil relationships. All teachers agreed that they provide different content activities depending on whether the class has low, middle or high achieving pupils.

The first research question states if there are any disparities in gender in a school that stream. School Y streams and class $\mathrm{A}$ is the highest stream followed by B class and lastly class $\mathrm{E}$ is the lowest stream.

Table2. Streams in school $\mathrm{Y}$ and gender distribution by class

\begin{tabular}{|c|c|c|c|c|c|}
\hline \multicolumn{6}{|c|}{ School Y } \\
\hline \multirow[t]{2}{*}{ Class } & \multirow[t]{2}{*}{ Class size (n) } & \multicolumn{2}{|c|}{ Male } & \multicolumn{2}{|c|}{ Female } \\
\hline & & $\mathrm{n}$ & $\%$ & $\mathrm{n}$ & $\%$ \\
\hline A & 50 & 15 & 30 & 35 & 70 \\
\hline B & 41 & 22 & 53 & 19 & 46 \\
\hline $\mathrm{C}$ & 42 & 24 & 57 & 18 & 43 \\
\hline $\mathrm{D}$ & 40 & 21 & 53 & 19 & 47 \\
\hline$E$ & 20 & 13 & 65 & 7 & 35 \\
\hline Total & 193 & 95 & & 98 & \\
\hline
\end{tabular}

Table 2 and figure 1 indicate that girls are more represented in class A-the highest stream ( $\mathrm{f}=35$ versus $\mathrm{m}=$ 15 ), that is $70 \%$ of girls are represented, and are lowest in class $E$, the lowest stream ( $f=7$ versus $m=15$ ), representing $31.8 \%$ girls. The middle stream, class $\mathrm{C}$ has more boys than girls. Boys are more represented in classes B to E.

Figure 1. Gender frequencies per class

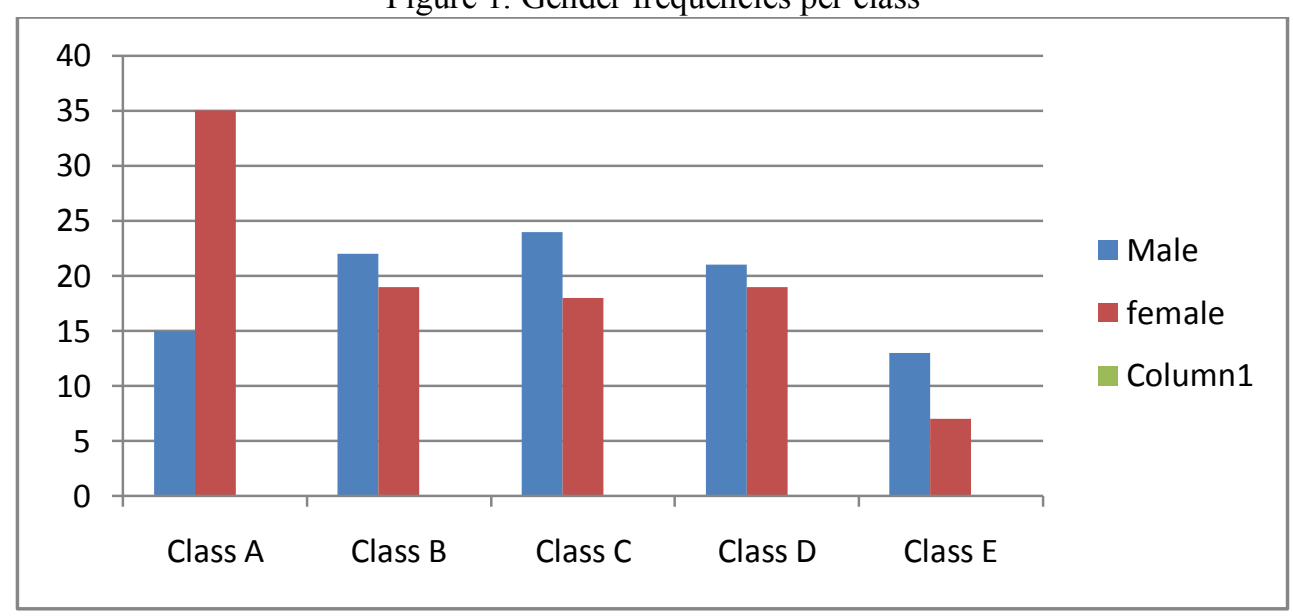

The second research question compares the variations in pupils' achievement within a school that stream and not. To determine this, means and standard deviations were computed for each of the grade 5 classes in a nonstreaming school (school X) and a school that streams (school Y). The overall means and standard deviations for each school were also computed. In school $\mathrm{Y}$, the ' $A$ ' class is the upper stream whereas the ' $E$ ' class is the lowest.

Table 3. Means and standard deviations for classes in school $\mathrm{X}$ and $\mathrm{Y}$

\begin{tabular}{|c|c|c|c|c|c|c|c|}
\hline \multicolumn{4}{|c|}{ School X } & \multicolumn{4}{|c|}{ School Y } \\
\hline Class & $\begin{array}{ll}\text { Sample } & \text { size } \\
\text { (n) } & \end{array}$ & Mean Score & Stddev (s) & Class & Sample size (n) & Mean & $\begin{array}{l}\text { Std dev } \\
\text { (s) }\end{array}$ \\
\hline A & 58 & 33.19 & 2.86 & A & 50 & 37.76 & 2.53 \\
\hline B & 46 & 29.65 & 2.26 & B & 41 & 35.25 & 2.85 \\
\hline $\mathrm{C}$ & 48 & 29.73 & 1.76 & $\mathrm{C}$ & 42 & 32.48 & 2.86 \\
\hline & & & & D & 40 & 30.33 & 2.64 \\
\hline & & & & $\mathrm{E}$ & 20 & 27,65 & 3.65 \\
\hline
\end{tabular}




\begin{tabular}{|l|l|l|l|l|l|l|l|}
\hline Overall & 152 & 31.02 & 2.91 & 193 & 33.49 & 4.37 \\
\hline
\end{tabular}

In class $\mathrm{A}$ and class $\mathrm{C}$ in schools $\mathrm{X}$ and $\mathrm{Y}$ respectively have similar variations (2.86) in pupils' achievement scores. However, the highest variability occurred in the lowest stream (3.65) in school Y and the lowest occurred in school X, class C (1.76). There appears to be no relationship between the means and the standard deviations. School X standard deviations ranged from 1.76 to 2.86 while in school $\mathrm{Y}$ they ranged from 2.53 to 3.65. The overall standard deviations indicate greater variability in school $\mathrm{Y}(\mathrm{s}=4.37)$ and less in school $\mathrm{X}(\mathrm{s}=$ 2.91).

The third research question states if there are any achievement differences within each grade in nonstreaming and streaming schools. To determine this, obtained mean scores for each grade were transformed to grade equivalent (using the WRAT-R LI) and compared to the expected score of grade 5 which is 30 (annex 2 for conversions). For example $6 \mathrm{~B}$ refers to pupils achieving at lower sixth grade level; $6 \mathrm{M}$ are those pupils operating at mid-sixth grade level and $6 \mathrm{E}$ entails those pupils achieving at upper sixth grade level.

Table 4. Mean scores and the grade equivalent for schools $X$ and $Y$

\begin{tabular}{|c|c|c|c|c|c|c|c|c|c|}
\hline \multicolumn{5}{|c|}{ School X } & \multicolumn{5}{|c|}{ School Y } \\
\hline Class & $\begin{array}{l}\text { Obtained } \\
\text { mean Score }\end{array}$ & $\begin{array}{l}\text { Grade } \\
\text { equivalent }\end{array}$ & $\begin{array}{l}\text { Expected } \\
\text { score }\end{array}$ & $\begin{array}{l}\text { Grade } \\
\text { equiva }\end{array}$ & Class & $\begin{array}{l}\text { Obtained } \\
\text { mean } \\
\text { score }\end{array}$ & $\begin{array}{l}\text { Grade } \\
\text { equivalent }\end{array}$ & $\begin{array}{l}\text { Expected } \\
\text { mean } \\
\text { score }\end{array}$ & $\begin{array}{l}\text { Grade } \\
\text { equiva }\end{array}$ \\
\hline $\mathbf{A}$ & 33.19 & $6 B$ & 30 & 5B & $\mathbf{A}$ & 37.76 & 8B & 30 & $5 B$ \\
\hline B & 29.65 & 5B & 30 & 5B & B & 35.25 & $7 B$ & 30 & $5 B$ \\
\hline $\mathbf{C}$ & 29.73 & 5B & 30 & 5B & $\mathbf{C}$ & 32.48 & $6 B$ & 30 & 5B \\
\hline & & & & & D & 30.33 & 5B & 30 & $5 B$ \\
\hline & & & & & $\mathbf{E}$ & 27,65 & $4 B$ & 30 & 5B \\
\hline
\end{tabular}

Table 4 indicates that in school X, class $\mathrm{A}$ is achieving at lower sixth grade (a grade above their current grade 5 placements) and the other two classes are achieving at lower fifth grade which is equivalent to their current grade placement. The mean score differences between class A (with highest mean) and class B (with lowest mean) is 3.54 while the grade equivalent differences (6B and $5 \mathrm{~B}$ ) is 1 (one) grade which is equivalent to one year of education. Thus, the achievement lag between these classes is one year. The achievement levels in school Y range from lower grade 8 (highest stream) to lower fourth grade (4B) which is the lowest stream. The pupils are achieving at above grade 5 level (classes A to D) and below (class E). In general, the achievement levels decreases as pupils find themselves in lower streams. The difference in mean scores between the highest stream (class A) and lowest stream (class $\mathrm{E}$ ) in school $\mathrm{Y}$ is 10.11 while grade equivalent differences (between $8 \mathrm{~B}$ and 4B) is 4 grades which equates to an achievement lag of 4 years in education.

Figure 2. differences in mean scores between school $\mathrm{X}$ and school $\mathrm{Y}$ in each class.

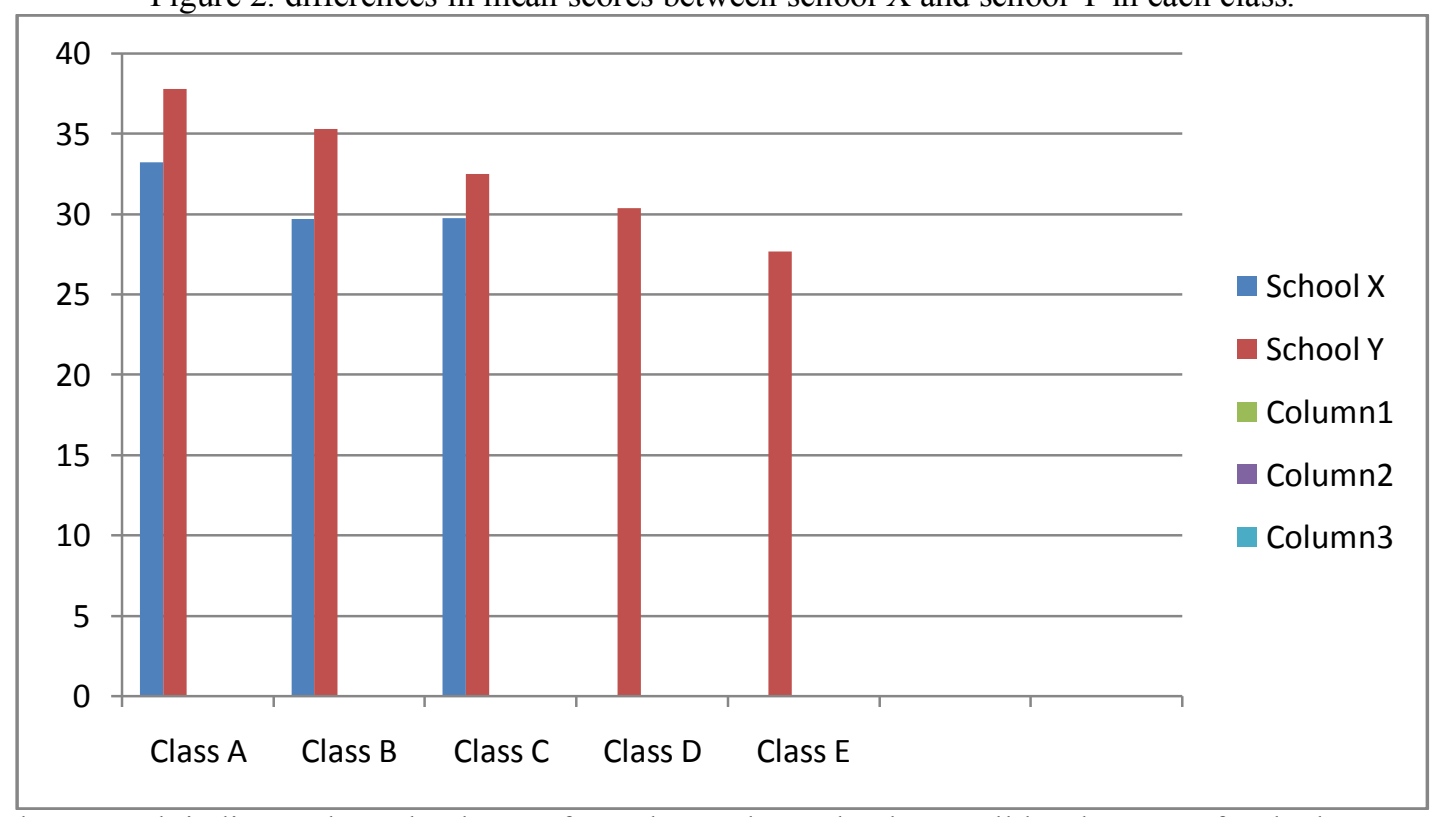

The above graph indicates that school Y performs better than school $\mathrm{X}$ at all levels except for the lowest stream (class E).

The first hypothesis states that there are no significant differences in pupils' achievement between nonstreaming and streaming grade 5 pupils. 
Table 5. t-test table showing sample sizes (n), means and standard deviations for schools X and Y.

\begin{tabular}{|l|c|c|c|c|}
\hline & School X & School Y & d.f. & t-value \\
\hline Total score & 4716 & 6464 & 345 & \multirow{2}{*}{104.24} \\
\cline { 1 - 3 } Sample size & 152 & 193 & & \\
\hline Mean & 31.02 & 33.49 & & \\
\hline
\end{tabular}

There are high significant differences in pupils' achievements between a school that does not stream and the one that practice streaming: $\mathrm{t}(345)=-104.24, \alpha=0.01$. School $\mathrm{Y}$ is achieving better overall.

\section{Discussion}

Teachers agree that the high teacher-pupil ratio impacts negatively with teaching and teacher-student relationships while teacher expectations differ according the level of the stream employed. This concurs with studies by Pollard et al., (1991), and Hallam and Ireson, (2005) and Wiliam and Bartholomew, (2004) respectively. Studies have shown that positive teacher relationships are related to academic achievement ( Hamre and Pianto, 2001). Teacher expectations have been shown to impact on student learning opportunities (Rubie-Davies et al., 2006)

The findings indicate that girls are more represented in the upper stream while boys are in the lower stream. Interviews with teachers indicated that streaming at school $\mathrm{Y}$ begins at grade 2 level hence the achievement differences might not be attributed to ability but the way teachers' perceive girls in terms of being passive and less disruptive than boys (Crocker and Cheeseman, 1991). However, there are increasing reasons to believe that what happens in the earliest years in schooling may set students on a path to either success or increasing chances for failure (Entwistle et al., 1997; Phillips et al., 1998).

Greater variability in mathematics test scores as measured by standard deviations was found in a school that streams indicating substantial inequalities within the school which might be attributed to selective procedures used in schools or policies applied by the school thus different groups of pupils within the school encountered different teaching learning environments.

The high stream class performed three grades above their grade placement while the lowest stream was achieving a grade below. The grade differences between high stream and low steam translates to 4 years education. There was a variation of one year in a non streaming school. This concurs with reviews by Slavin (1990) and Boaler (1997) who concluded that streaming only benefits students in the top ability group. Similarly, Kerckhohoff (1986) showed that students to selective classes increased their achievement more than similar students who enrolled in mixed ability classes while students in the low-level classes fell further and further behind. Previous research ( Boaler, William and Brown, 2000; William and Bartholomew, 2004) has found that teachers alter classroom practices, providing different content and activities depending on whether a class contains low, middle or high achieving learners. Also, assigning pupils to low ability classrooms call for expectation for pupils that become self-fulfulling prophecies (Nachmias, 1977, in Reuman, 1989). Thus pupils have negative affect toward school due to their low academic self-concept. Also, Hallinan and Sorensen (1983) report that when pupils are moved to lower-ability group it disturbs their self-esteem and lose motivation and learn less than if they were not grouped

The findings indicate highly significant differences in achievement between streamed and mixed ability schools with a streamed school being better off. Kerckhoff (1986) and Hoffer (1992) found similar results for mathematics achievement which strongly supported the theory differential effects, whereby students in highergrouped classrooms learned more compared to their non-grouped students. Also, Heras and Rangel (2009), study strongly supports the differential effects hypothesis of ability grouping. However, a study by Betts and Shkolnik (2000) found little to no effects of grouping for mathematics instruction on the mathematics growth among middle school students after taking into account differences in class ability levels. Thus their study estimated the effects of ability grouping within classes of similar average ability levels in order to better estimate the effects of grouping for instruction.

\section{Conclusion}

The results indicate that more girls are represented in the high stream while boys are more in the low stream. The high and middle streams are achieving at above grade 5 level while the low stream is performing a grade below grade 5 . There is a 4 year difference in education between high and low streams. The nonstreaming school has no class achieving at below grade 5 level and the difference between the high and low classes performances is one year in education they are significant differences in performances between a nonstreamed and a streamed school with a streamed school doing better. This supports the differential hypothesis of ability grouping. 


\section{References}

[1]. Allington, R.L. (1994). The schools we have. The schools we need. The Reading Teacher, 48 (1), 14 29.

[2]. Atkinson, N.D. (1982). Racial integration in Zimbabwean schools, 1979-1980. Comparative Education, 18, 1, 77-89.

[3]. Boaler, J. (1997). Experiencing School Mathematics: Teaching styles, sex and setting. Buckingham: Open University Press.

[4]. Boaler, J. (2002) Experiencing school mathematics: Traditional and reform approaches to teaching and their impact on student learning. Mahwah, NJ: Erlbaum.

[5]. Boaler, J (2008a). Helping children learn to love their least favorite subject—and why it's important for America. New York: Penguin.

[6]. Boaler, J. (2011). Changing Students' Lives Through the De-Tracking of Urban Mathematics Classrooms. Journal of Urban Mathematics Edducation 4(1) 7-14.

[7]. Boaler, J., Wiliam, D., \& Brown, M. (2000). Students' experiences of ability grouping-disaffection,

[8]. polarization and the construction of failure. British Educational Research Journal, 26, 632-48.

[9]. Burris, C., Heubert, J., \& Levin, H. (2006). Accelerating mathematics achievement using hetero-geneous grouping. American Educational Research Journal, 43, 103-134.

[10]. Campbell, D. T., \&: Stanley,]. C. (1963). Experimental and quasi-experimental designs for research. Boston, MA: Houghton Mifflin.

[11]. Chisaka, B. (1996). An Investigation into the Ability grouping of „O'Level History Pupils and how this relates to Social Stratification with special reference to Harare. Unpublished doctoral theses.

[12]. Crocker, T., \& Cheeseman, R. (1991). The ability of young children to rank themselves for academic ability. In M. Woodhead, P. Light \& R. Carr (Eds.), Growing up in a Changing Society (pp. 156-162). London: Routledge and The Open University.University of Zimbabwe.

[13]. Entwisle, D. R., Karl L. A., and Linda S. O. (1997). Children, Schools and Inequality. Boulder, CO: Westview.

[14]. Heras, C and Rangel, C. (2009) Ability Grouping Practices in Elementary School and African American/Hispanic achievement. American journal of Education,115, 281-304

[15]. Hallam, S. \& Ireson, J. (2003). Secondary school teachers' attitudes towards and beliefs about ability grouping. The British Journal of Educational Psychology, 73, 343-56.

[16]. Hallam, S. \& Ireson, J. (2006). Secondary school pupils' preferences for different types of structured grouping practices. British Educational Research Journal, 32, 583-99.

[17]. Hamre, B.K. \& Pianta, R. C. (2001). Early Teacher-Child Relationships and the Trajectory of Children's School Outcomes Through Eighth Grade. Child Development, 72(2), 625-638.

[18]. Hoffer, T. (1992). "Middle School Ability Grouping and Student Achievement in Science and Mathematics." Education Evaluation and Policy Analysis 14 (3): 205-27

[19]. Jung, M. (2000). Ability grouping and equity of educational opportunity. The Journal of Curriculum Studies, 18, 275-97.

[20]. Kerchkoff, A.C. (1986) Effects of ability grouping in British secondary schools, American Sociological Review, 51(6), 842-858.

[21]. Kulik, J.A. (1992). An analysis of the research on ability grouping: Historical and contemporary perspectives. Storrs, CT: National Research Center on the Gifted and Talented.

[22]. Ireson, J. \& Hallam, S. (2001). Ability grouping in education. London: Paul Chapman.

[23]. Ireson, J., Hallam, S., \& Hurley, C. (2005). What are the effects of ability grouping on GCSE attainment? British Educational Research Journal, 31, 443-58.

[24]. Irvine, P.D. \& Larson, J. (2001). Literacy packages in practice: Constructing academic disadvantage. In J. Larson (Ed.), Literacy as snake oil: Beyond the quick fix. New York: Peter Lang.

[25]. Macqueen, S.(2010) Primary teacher attitudes in achievement based literacy classes. Issues Educational Research, 20(2) 118-133

[26]. Matavire, M., Mukavhi, L \& Sana, A. L. (2012) Homgenous Grouping and Mixed Ability: A comparative approach on two secondary schools in Muzarabani District, Zimbabwe. International Journal of Humanities and Social science 2(4)

[27]. Nkoma, E., Zirima, H., Chimunhu, J., and Nyanga, T. (2013) Tracking Learner Achievement Gap: An analysis of mathematics achievement in Manicaland, Zimbabwe. Internationl Journal of economy, Management and Social Sciences 2(5) 124-132.

[28]. Nunes, T., Bryant, P., Sylva, K., \& Barros, R. (2009). Development of maths capabilities and con-fidence in primary school (Research Report No. DCSF-RP118). Retrieved from Department of Children, Schools, and Families https://www.education.gov.uk/publications/eOrderingDownload/DCSF-RR118.pdf.

[29]. Oakes, J. (1985). Keeping track: How schools structure inequality. New Haven, CT: Yale University Press.

[30]. Phillips, M., James., and John, R. 1998. "Does the Black-White Test

[31]. Score Gap Widen after Children Enter School?” In The Black-White Test Score Gap, ed. C. Jencks and M. Phillips. Washington, DC: Brookings Institution.

[32]. Pollard, A., Osborn, M., Croll, P. Abbott, D. \& Broadfoot, P. (1991). Classroom Change and Pupil Experience. Paper presented at the American Educational Research Association Conference, Chicago.

[33]. Reuman, (1989).How social comparison mediates the relation between ability-grouping practices and students' expectancies in mathematics, Journal of Educational Psychology, 81(2), 178-189.

[34]. Shadish, W. R., Cook, T. D., and Campbell, D. I. (2002). Experimental and quasi-experimental designs for generalized causal inference. Boston, MA: Houghton Mifflin.

[35]. Slavin, R.E. (1987). Grouping for instruction in the elementary school. Educational Psychologist, 22, 109-27.

[36]. Slavin R.E. \& Braddock, J.H. (1993) Ability grouping: on the wrong track The College Board Review, 68(2), 11-17.

[37]. Wiliam, D. \& Bartholomew, H. (2004.) It's not which school but which set you're in that matters: The influence of ability grouping practices on student progress in mathematics. British Educational Research Journal, 30(2), 279-293.

[38]. Zindi, F. (1996). Towards the elimination of disparities in educational provision: A look at Zimbabwe and South Africa. Journal of Social Development in Africa, 11, 1, 43-51. 


\section{Annex 1}

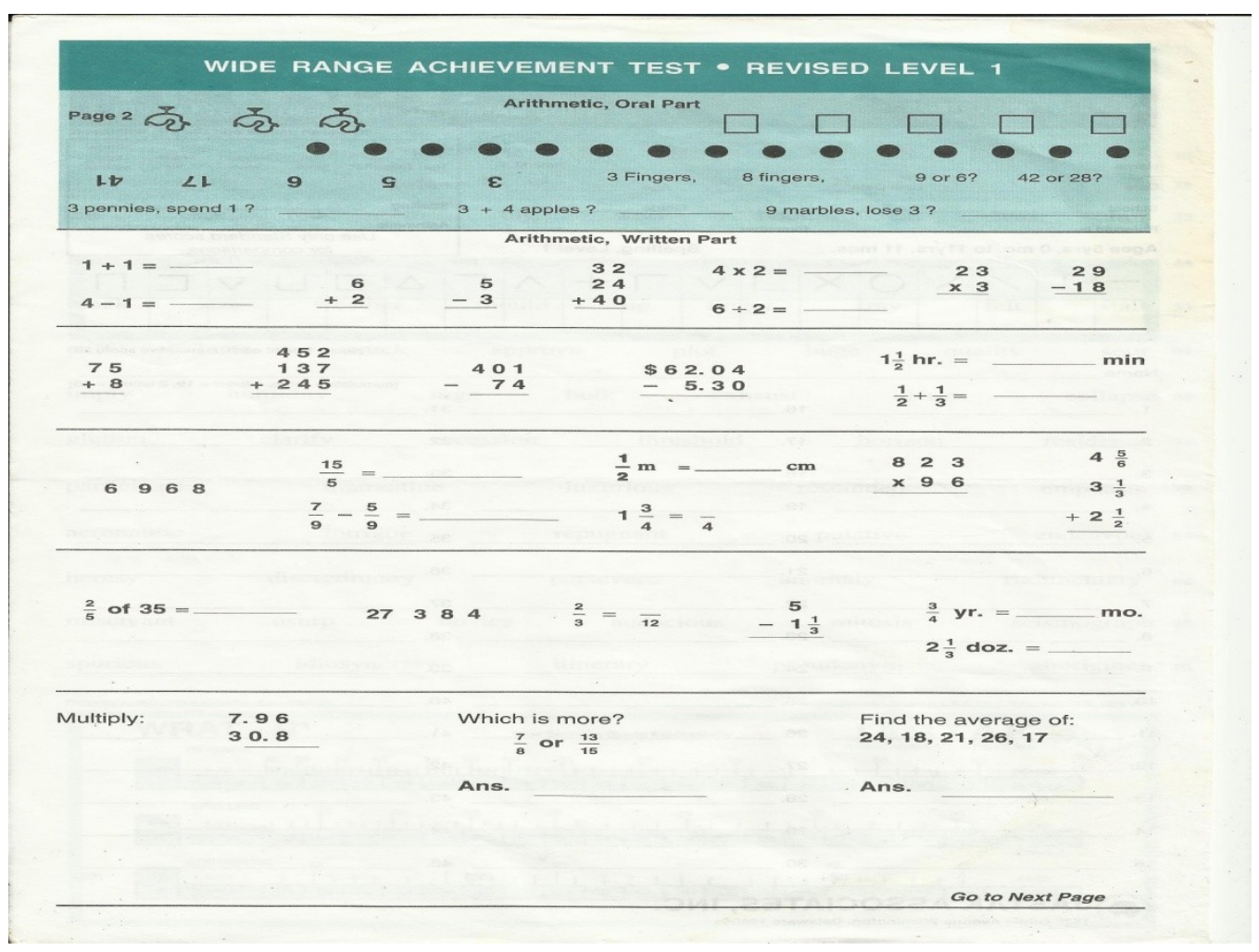

Annex 2

Transformation of scores to grade equivalent

\begin{tabular}{|l|l|l|l|l|l|l|l|l|l|l|l|l|l|l|l|l|l|l|l|}
\hline score & $1-13$ & 14 & $\begin{array}{l}15- \\
16\end{array}$ & $\begin{array}{l}17- \\
18\end{array}$ & 19 & 20 & $\begin{array}{l}21- \\
22\end{array}$ & $\begin{array}{l}23- \\
24\end{array}$ & $\begin{array}{l}25- \\
26\end{array}$ & 27 & $\begin{array}{l}28- \\
29\end{array}$ & 30 & 31 & $\begin{array}{l}32- \\
33\end{array}$ & $\begin{array}{l}34 \\
35-\end{array}$ & $\begin{array}{l}37 \\
38-\end{array}$ & $\begin{array}{l}40 \\
39\end{array}$ \\
\hline $\begin{array}{l}\text { Grade } \\
\text { equiv }\end{array}$ & $\begin{array}{l}\text { Pre- } \\
\text { first }\end{array}$ & 1B & $1 \mathrm{M}$ & $\mathbf{1 E}$ & 2B & 2M & 2E & 3B & 3E & 4B & 4E & 5B & 5E & 6B & 6E & $7 \mathrm{~B}$ & $7 \mathrm{E}$ & $\mathbf{8 B}$ & $\mathbf{8 E}$ \\
\hline
\end{tabular}

Questionnaire for teachers and Headmasters

1. Who assigns teachers to classes/streams?

Cross the most appropriate response for questions 2 up to 12

2. High teacher-pupil ratio impact negatively on teaching and teacher-pupil relationships
Strongly agree Agree
Neutral
disagree

3. High achieving pupils benefit from working with similar peers
Strongly agree Agree
Neutral
disagree

strongly disagree

4. Lower achieving pupils benefit from working with high achieving pupils

$$
\text { Strongly agree Agree Neutral disagree }
$$

5. Low achieving pupils in low stream develop lower self esteem

$$
\text { Strongly agree Agree Neutral disagree }
$$

6. Academic standards improve with steaming in schools

Strongly agree Agree Neutral disagree strongly disagree

7. Moral for high and middle stream teachers is high

$\begin{array}{llll}\text { Strongly agree Agree } & \text { Neutral } & \text { disagree } & \text { strongly disagree }\end{array}$

8. Morale is low in low stream teachers

Strongly agree Agree Neutral disagree

9. The least experienced teachers are assigned to low stream classes
Strongly agree
Agree
Neutral
disagree

10. The highly experienced teachers are assigned to high stream classes
Strongly agree
Agree
Neutral
disagree

11. Teacher expectation/instruction differ according to the level of streaming Strongly agree Agree Neutral disagree

12. Teachers provide different content/activities depending on whether they are in the low, middle or high stream
Strongly agree
Agree
Neutral
disagree
strongly disagree

strongly disagree

strongly disagree

strongly disagree

strongly disagree 